University of Nebraska - Lincoln

DigitalCommons@University of Nebraska - Lincoln

\title{
Short-term Disruption of a Leafy Spurge (Euphorbia esula) Biocontrol Program Following Herbicide Application
}

\author{
Diane L. Larson \\ USGS Northern Prairie Wildlife Research Center, dlarson@usgs.gov \\ James B. Grace \\ USGS National Wetlands Research Center, Lafayette, LA, gracej@usgs.gov \\ Paul A. Rabie \\ University of Minnesota, St.Paul, prabie@west-inc.com \\ Paula Andersen \\ Theodore Roosevelt National Park
}

Follow this and additional works at: https://digitalcommons.unl.edu/usgsnpwrc

Part of the Other International and Area Studies Commons

Larson, Diane L.; Grace, James B.; Rabie, Paul A.; and Andersen, Paula, "Short-term Disruption of a Leafy Spurge (Euphorbia esula) Biocontrol Program Following Herbicide Application" (2007). USGS Northern Prairie Wildlife Research Center. 84.

https://digitalcommons.unl.edu/usgsnpwrc/84

This Article is brought to you for free and open access by the US Geological Survey at DigitalCommons@University of Nebraska - Lincoln. It has been accepted for inclusion in USGS Northern Prairie Wildlife Research Center by an authorized administrator of DigitalCommons@University of Nebraska - Lincoln. 


\title{
Commentary
}

\section{Short-term disruption of a leafy spurge (Euphorbia esula) biocontrol program following herbicide application}

\author{
Diane L. Larson ${ }^{\mathrm{a}, *}$, James B. Grace ${ }^{\mathrm{b}}$, Paul A. Rabie ${ }^{\mathrm{c}, 1}$, Paula Andersen ${ }^{\text {d,2 }}$ \\ ${ }^{a}$ USGS Northern Prairie Wildlife Research Center, Minnesota Field Station, 100 Ecology Building, 1987 Upper Buford Circle, St. Paul, MN 55108, USA \\ ${ }^{\mathrm{b}}$ USGS National Wetlands Research Center, Lafayette, LA, USA \\ ${ }^{\mathrm{c}}$ University of Minnesota, St. Paul, MN, USA \\ d Theodore Roosevelt National Park, Medora, ND, USA
}

Received 15 May 2006; accepted 29 August 2006

Available online 6 September 2006

\begin{abstract}
Integrated pest management (IPM) for invasive plant species is being advocated by researchers and implemented by land managers, but few studies have evaluated the success of IPM programs in natural areas. We assessed the relative effects of components of an IPM program for leafy spurge (Euphorbia esula), an invasive plant, at Theodore Roosevelt National Park, North Dakota. Effects of herbicides on leafy spurge abundance and on dynamics of flea beetles (Aphthona spp.) used to control leafy spurge were evaluated over three field seasons following herbicide application. We monitored leafy spurge-infested plots with established flea beetle populations that had received picloram plus 2,4-D in September 1997 or 1998, imazapic in September 1998, versus those with no chemical treatment. Mature stem counts did not differ significantly between treated and untreated plots in 2001, suggesting that leafy spurge stands had recovered from herbicide treatment. Flea beetles were less abundant on plots with a history of herbicide treatment. Structural equation models indicated that in 2000 negative correlations between relative abundances of the two flea beetle species were greater on plots that had received herbicide treatments than on those that had not, but by 2001 no differences were apparent between treated and untreated plots. These results suggest that the most effective component of IPM for leafy spurge at this site is biological control. All herbicide effects we observed were short-lived, but the increased negative correlation between flea beetle relative abundances during 2000 implies that herbicide application may have temporarily disrupted an effective biological control program at this site.
\end{abstract}

(C) 2006 Elsevier Inc. All rights reserved.

Keywords: Aphthona; Biological control; Euphorbia esula; Herbicide; Integrated pest management; Mixed-grass prairie; Theodore Roosevelt National Park

\section{Introduction}

Integrated pest management (IPM) strategies are advocated by researchers and extension agents in response to nonnative plant invasions (e.g., Lym, 1998; Mortensen et al., 2000; van Wilgen et al., 2000). Although there is a

\footnotetext{
* Corresponding author. Fax: +1 6126246777.

E-mail address: dlarson@usgs.gov (D.L. Larson).

${ }^{1}$ Present address: School of Biological Sciences, Washington State University, Pullman, WA, USA.

${ }^{2}$ Present address: USDA Forest Service, Little Missouri National Grasslands, Williston, ND, USA.
}

growing body of work on IPM in croplands and rangelands (Hollingsworth and Coli, 2001; Holtzer et al., 1996), few studies have evaluated IPM strategies in natural areas. Likewise, there is a dearth of studies devoted to interactive effects of herbicide and biological control (Ainsworth, 2003). IPM can be especially attractive in natural areas such as national parks, where economic thresholds for successful control are poorly defined and park management objectives may require varied levels of control. For example, dense infestations of nonnative plants may require substantial investment in herbicide, but infestations near especially sensitive habitat may be better managed with biocontrol. 
Here we use structural equation modeling (SEM) and observational data to evaluate components of IPM applied to a leafy spurge (Euphorbia esula L.) infestation in a national park in the mixed-grass prairie of western North Dakota. Treatments were applied as part of the park's management plan for leafy spurge, rather than as a designed experiment, which imposes constraints on conventional approaches to inference. SEM is a methodology in which observations are compared to the expectations derived from various a priori multivariate hypotheses (Grace, 2006) in order to determine what is implied about the processes in operation. This method has been widely employed in many disciplines and is proving to be increasingly valuable in the study of natural systems (Pugesek et al., 2003; Shipley, 2000).

Leafy spurge is a perennial clonal forb, native to Eurasia, which invades floodplains, woodlands, and upland prairie in North America (Lym, 1998). It is on the noxious weed lists of 21 states (USDA and NRCS, 2006). Leafy spurge is not palatable to most ungulates, displaces native plant species, and in many cases is able to invade apparently undisturbed vegetation (Belcher and Wilson, 1989; Butler and Cogan, 2004; Butler and Trammell, 1995; Larson et al., 2001). Theodore Roosevelt National Park (TRNP), a large native-dominated mixed-grass prairie in western North Dakota, USA, is home to a large infestation of leafy spurge; a 1993 estimate from aerial photography indicated 1300 ha of leafy spurge in the 18,600 ha South Unit of the park (7\%) (Anderson et al., 1996). Certain vulnerable habitats, such as the cottonwood-Rocky Mountain juniper communities of the riparian zone, have suffered almost complete invasion.

The IPM strategy for leafy spurge at TRNP includes the use of several herbicides and biological control agents. Biological control of leafy spurge in the northern Great Plains has been dominated by Aphthona spp. (flea beetles; Chrysomelidae), especially Aphthona lacertosa Rosenberg and Aphthona nigriscutis Foudras. These univoltine specialists were imported from Eurasia in the early 1980s (Hansen et al., 1997) and require leafy spurge to complete their life cycle (Gassmann et al., 1996). Adults feed on leaves and flowers, but damage is believed to be inflicted primarily by larvae, which burrow into roots, possibly disrupting nutrient flow and providing access points for fungal pathogens (Caesar, 2003). Flea beetles were first released at TRNP in 1986, and since then more than 3.8 million flea beetles have been released or redistributed in the South Unit (TRNP, unpublished). Mixtures of A. lacertosa and A. nigriscutis are effective biocontrol agents in areas similar to TRNP in the northern Great Plains (Kirby et al., 2000; Lym and Nelson, 2000).

Herbicides have been used to control leafy spurge at TRNP since 1960, but use increased dramatically in the mid-1990s: since 1994 140-210 ha per year have been treated in the park with more than a dozen different formulations, mostly by aerial applications. Picloram (4-amino-3,5,6-trichloropicolinic acid) with 2,4-D [(2,4-dichlorophenoxy) acetic acid] and imazapic \{2-[4,5-dihydro-4-methyl-4-(1methyl-ethyl)-5-oxo-1 $\underline{\mathrm{H}}$ - imidazol-2-y]-5-methyl-pyridine carboxylic acid $\}$ are the two herbicide formulations most commonly used in the park, and are the ones considered in this study.

This study evaluates one aspect of the IPM program for leafy spurge at TRNP, the relationship between herbicide application and established biocontrol insects. Because budgets for invasive species control are limited, it is important to evaluate the relative benefits of herbicide application in areas where biocontrol insects have been released. We used a retrospective approach to examine effects of prior aerial applications of herbicide applied as part of the park's leafy spurge management plan. Specifically, we ask, are herbicides related to leafy spurge abundance, flea beetle dynamics, and their interaction within the park? If so, what are the implications for effective management of leafy spurge?

\section{Materials and methods}

\subsection{Study site and plot establishment}

This study was conducted between 1999 and 2001 in the South Unit of Theodore Roosevelt National Park, Medora, North Dakota $\left(47^{\circ} \mathrm{N}, 104^{\circ} \mathrm{W}\right)$. The climate is continental with short, hot summers and long, cold winters. Long-term mean annual precipitation is $379 \mathrm{~mm}$, most of which falls between April and September. Precipitation, measured at Medora, North Dakota, on the border of the park, was below the 30-year mean all three years of the study, ranging from $312 \mathrm{~mm}$ in 2001 to $323 \mathrm{~mm}$ in 2000 (High Plains Regional Climate Center, http://www.hprcc.unl.edu).

The study took place in the wetter drainages and river terraces in the South Unit (Fig. 1) where herbicides had been applied in previous years. On 8-9 September 1997, potassium salt of picloram plus $2,4-\mathrm{D}$ amine $(0.6 \mathrm{~kg} / \mathrm{ha}$ plus $1.1 \mathrm{~kg} / \mathrm{ha}$, respectively) were applied by a helicopter equipped with a microfoil boom sprayer along the middle of the Paddock Creek drainage (Fig. 1). On 14 September 1998, the same herbicide mixture was applied by the same equipment to the western end of the drainage. On 15 September 1998, imazapic ( $140 \mathrm{~g} / \mathrm{ha}$ a.i. with $2.3 \mathrm{~L} / \mathrm{ha}$ methylated seed oil) was applied by fixed-wing aircraft to an infestation along the Little Missouri River at the northern boundary of the park. No pretreatment vegetation assessments were made. All herbicide applications were within the dwarf sagebrush (Artemisia cana Pursh) vegetation type, which is characterized by shrubs in a matrix of grasses (primarily Pascopyrum smithii (Rydb.) Á. Löve and Stipa viridula Trin.) and forbs such as Linum lewisii Pursh., Achillea millefolium L., and Artemisia frigida Willd.

In 1999, we established $2013 \mathrm{~m} \times 5 \mathrm{~m}$ permanently marked vegetation plots within the infested dwarf sagebrush vegetation type and subdivided each into 240 numbered, $0.25 \mathrm{~m} \times 0.25 \mathrm{~m}$ quadrats. One hundred eighteen plots were located at randomly selected flea beetle release points (which had been recorded on global positioning sys- 


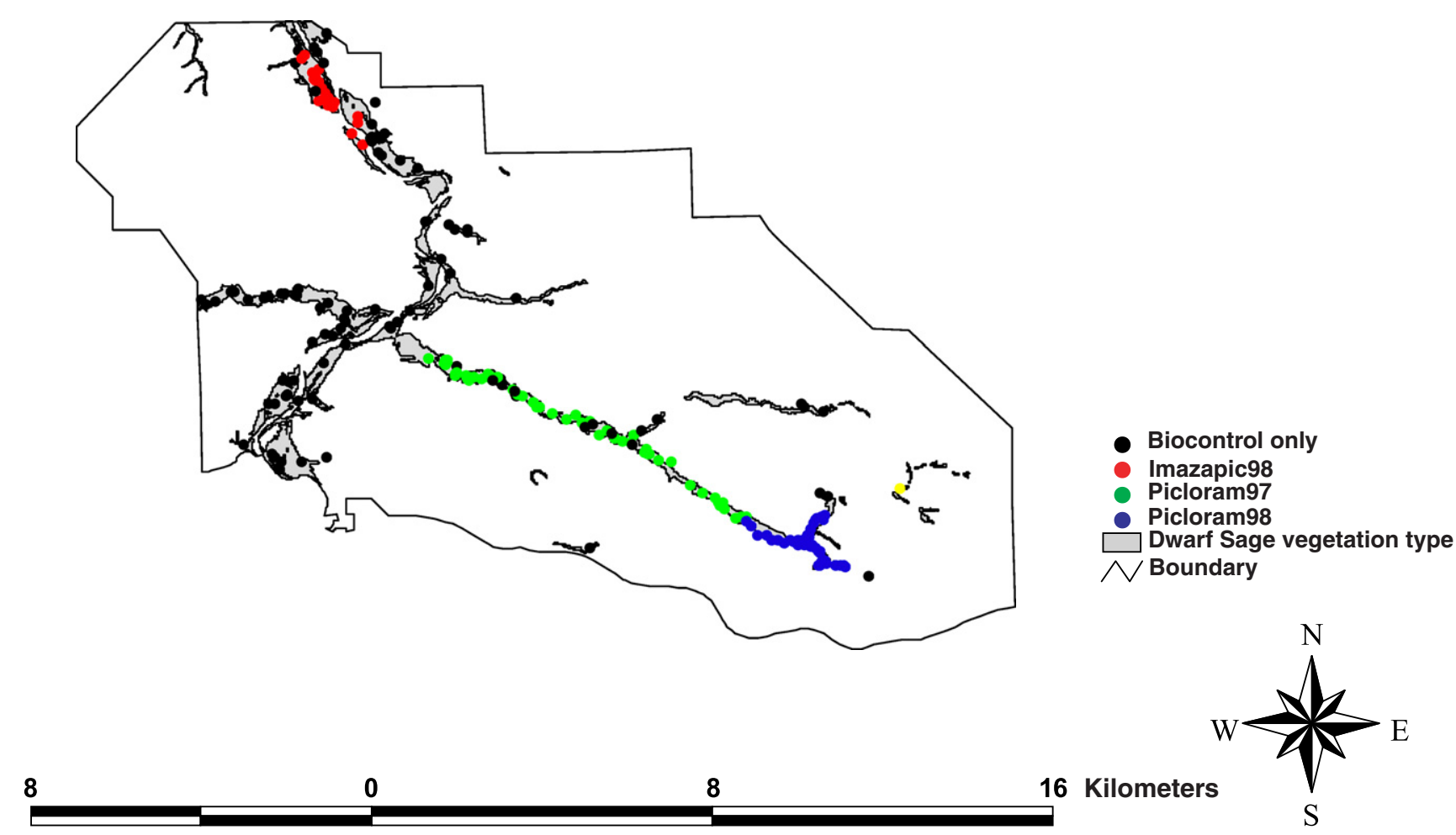

Fig. 1. Locations of herbicide and biocontrol-only plots within the dwarf sagebrush vegetation type at the South Unit of Theodore Roosevelt National Park, North Dakota.

tem units at the time of release, generally after 1994). The peak of A. lacertosa releases occurred in 1995 and 1996 with approximately 500,000 insects released within the dwarf sagebrush vegetation type alone each year, representing slightly more than half of all releases of $A$. lacertosa in the park in those years. Releases of $A$. nigriscutis peaked in 1996 with $>170,000$ insects released within the dwarf sagebrush vegetation type. Eighty-three sample points were at random nonrelease points that were infested with leafy spurge. Flea beetles were subsequently found to be present on all plots. The plots were initially established without regard to herbicide application. Forty-four plots fell within the area that had been sprayed with picloram/2,4-D in 1998 (hereafter, picloram98), 60 (of which we sampled 30 in 2000-2001) within the area sprayed with picloram/2,4-D in 1997 (hereafter, picloram97), 20 within the area sprayed with imazapic in 1998 (hereafter, imazapic98), and 77 (of which we sampled 22 in 2000-2001) within areas that had not been sprayed since at least 1996 (Fig. 1). The decline in sampled plots in 2000-2001 was the result of budget cuts; plots were randomly deleted from treatments containing the greatest number of plots (i.e., imazapic98 and picloram98).

\subsection{Vegetation sampling}

Leafy spurge stems were counted once in the spring (approximately May 20-June 20 of 1999-2001) on six randomly-selected quadrats per plot. No attempt was made to determine below ground connection among stems. We distinguished seedlings from mature stems by the presence of cotyledons and determined proportion of mature stems in flower in the counts. Both seedlings and flowering stems indicate a vigorous, reproducing population.

\subsection{Insect sampling}

We estimated relative abundance of adult flea beetles at each of the original plots in each year because we anticipated high variability in beetle numbers. Adult flea beetles were sampled once each season using $38-\mathrm{cm}$ sweep nets around the time of peak emergence (about 25 June-5 July) each year. The large number of plots made it impossible to sample more than once. Sampling was done when vegetation was dry, temperatures were $>20^{\circ} \mathrm{C}$ and wind speed was $<32 \mathrm{~km} / \mathrm{h}$. Because the sweep nets would damage the vegetation, insects were sampled around the perimeter of each vegetation plot and the number of flea beetles of each species was summed over the four edges of the plot perimeter as an indication of the relative abundance of the flea beetles at each plot.

\subsection{Statistical analysis}

All analyses of variance (ANOVA) were conducted with SAS (SAS Institute, 1999) using type III sums of squares. Counts were log-transformed and proportions were square root-transformed to reduce heterogeneity of variances. We used mixed-models ANOVA (PROC Mixed; SAS Institute, 1999) to test for differences in stem counts among years 
(1999, 2000, 2001), treatments (Aphthona only, picloram97, picloram98, and imazapic98) and their interaction. Plots were nested within herbicide treatments. For Aphthona analyses, we used repeated-measures ANOVA since entire plots were repeatedly sampled, in contrast to random quadrats within plots where stem counts were conducted. For Aphthona analyses, we pooled the three herbicide treatments into a single variable, herbicide history (treated or not), since it was not possible to distinguish direct effects of individual herbicides from their indirect effects by changes in stem counts using ANOVA. We used Fisher's LSD (Milliken and Johnson, 1984) to test for differences among treatments $(P=0.05)$.

Because herbicide treatments were in geographically distinct areas of the South Unit, we performed a canonical correspondence analysis using PcOrd software (McCune and Mefford, 1997) to determine how much of the variance in stem counts depended on geographic position. Only 5\% of log stem count variance was accounted for by synthetic axes that reflected standardized northings and eastings (data not presented). A similar analysis to assess geographic variation in flea beetle relative abundance indicated only $1.7 \%$ of the variance attributable to geographic position (data not presented). Subsequent ANOVA therefore did not take geographic position into account.

Because both flea beetle relative abundance and leafy spurge stem counts could depend on stem counts in the previous year, we used structural equation models (McCune and Grace, 2002, Chapter 30) to assess the contribution of the two flea beetle species and initial (1999 or 2000) stem counts to the change in mature stem counts between 1999 and 2000 and between 2000 and 2001. To compare the responses of the flea beetles and leafy spurge populations in herbicide and nonherbicide areas, we performed a multi-group analysis (Grace, 2003) using the software LISREL (Jöreskog and Sörbom, 1996) in which group one comprised plots in the herbicide-treated area and group two comprised plots in areas not sprayed with herbicide. Imazapic and picloram/2,4-D plots were combined for this analysis, resulting in 93 herbicide plots that were monitored in all three years of the study, with which we compared 164 nonherbicide plots from a related study over the same time period that used the same sampling methods (Larson and Grace, 2004). Our models addressed the following questions: (1) Are changes in numbers of mature stems related to initial stem densities? (2) Are changes in mature stem counts related to relative abundance of $A$. nigriscutis or $A$. lacertosa in either the current or previous year? (3) Does relative abundance of A. nigriscutis or A. lacertosa depend on abundance of leafy spurge stems? (4) Do the two flea beetle species appear to influence each other's relative abundance (Fig. 2)?

After constructing the multivariate models, we inspected the data for outliers, normality, and heteroscedasticity; evaluated the fit of our initial model (Fig. 2) and refined the model and reassessed fit (McCune and Grace, 2002). Because the models were constructed after data had been

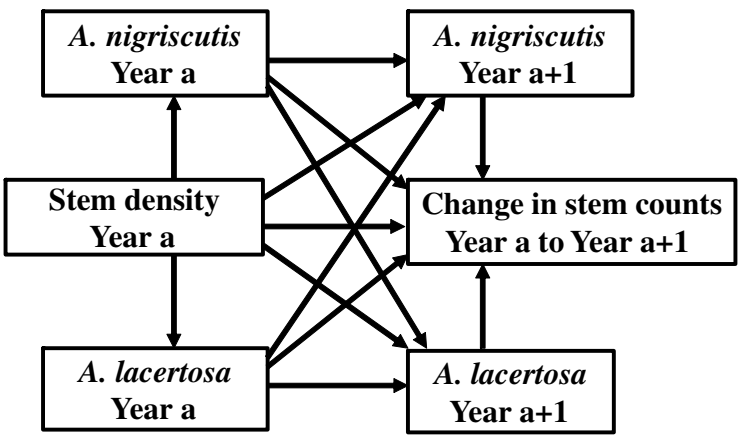

Fig. 2. Initial hypothesized model. Variables shown in boxes were measured in the field, so all are manifest variables. Arrows represent hypothesized causal relationships between the variable at the origin and the variable at the point of the arrow. The model was evaluated separately for two time periods: 1999-2000 and 2000-2001. A multi-group analysis was used to compare models for herbicide and nonherbicide plots.

collected, we consider our use of structural equations to be "model generating" rather than "strictly confirmatory" (Jöreskog and Sörbom, 1996).

We used Chi-square difference tests (Jöreskog and Sörbom, 1996) to compare variance, path coefficients, and means for the herbicide models with models developed for a set of 164 leafy spurge infested plots in the South Unit of TRNP that had not been treated with herbicide (Larson and Grace, 2004). Differences in the herbicide and nonherbicide models indicate potential effects of herbicide on interactions among A. lacertosa, A. nigriscutis, and leafy spurge. Note that Larson and Grace (2004) used plots throughout six vegetation types (including dwarf sagebrush), three of which included a significant overstory of trees, which tend to have lower flea beetle establishment than dwarf sagebrush habitats (see Larson and Grace (2004) Table 7), thus rendering our comparison conservative with respect to herbicide effects on flea beetles.

\section{Results}

\subsection{Stem counts}

Mature stems showed a significant treatment by year interaction $(F=3.43$; df $=6,222 ; P=0.0029$; Fig. 3a). Stem counts on imazapic 98 plots peaked in 2000 , but did not differ between 1999 and 2001. Stem counts on picloram 98 plots declined steadily and significantly each year. In contrast, stem counts remained steady throughout the study on picloram 97 plots. Nonetheless, by 2001, there were no significant differences among any of the treatments, including no herbicide, although stem counts tended to be less on herbicide plots.

Proportion of flowering stems declined for all treatments between 1999 and 2000, but leveled off between 2000 and 2001 (Fig. 3b); there was a significant treatment by year interaction $(F=3.76 ; \mathrm{df}=6,188 ; P=0.0015)$. Again, by 2001 there was little difference among treatments, although a smaller proportion of stems in picloram 97 plots were in flower than in picloram 98 plots. Seedling counts were sig- 
a Mature stems

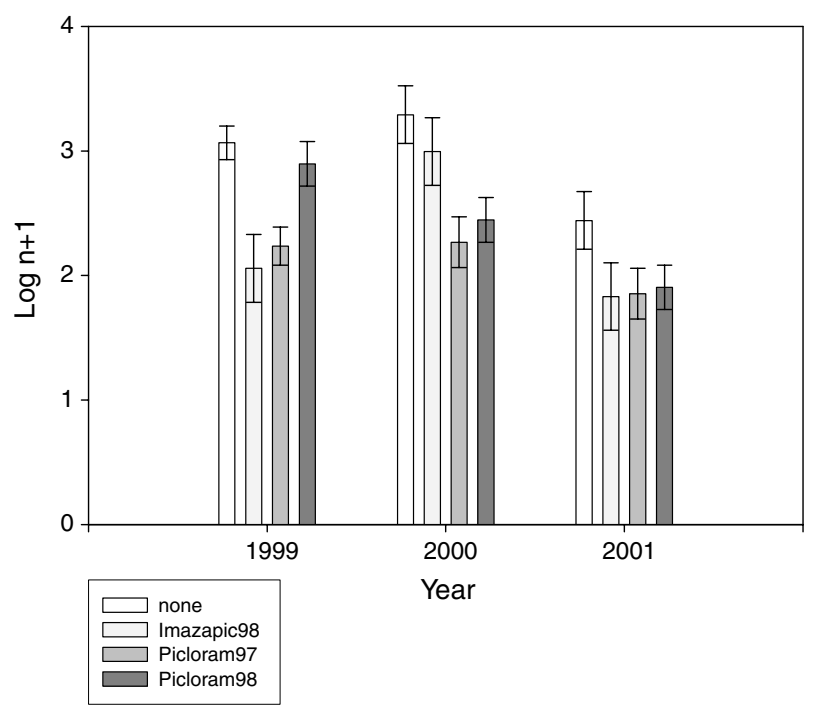

b Proportion stems in flower

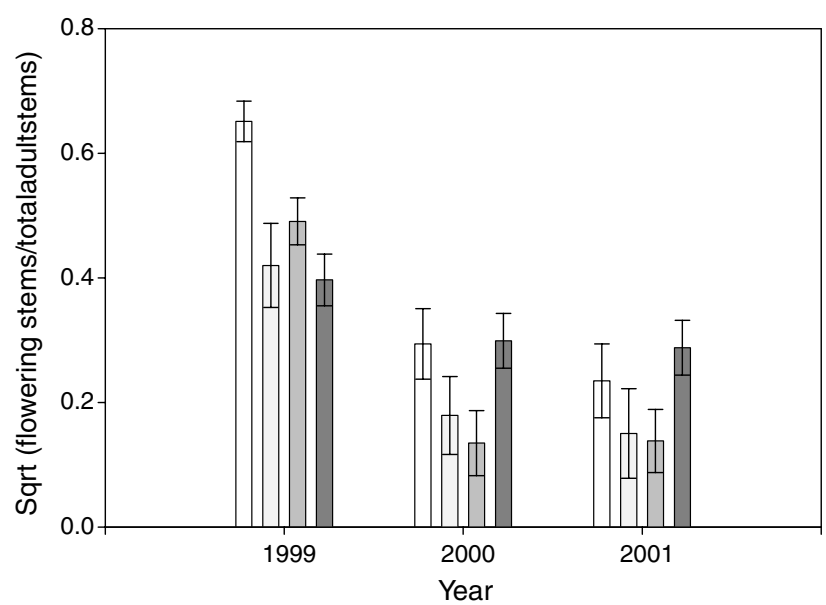

c Seedlings

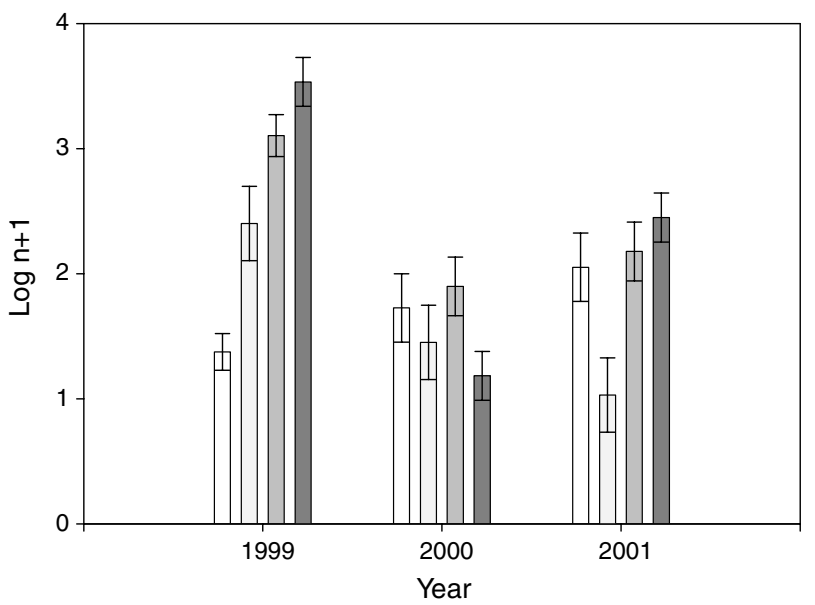

Fig. 3. Counts of leafy spurge mature stems, proportion of flowering stems, and seedling counts. Shown are least square means and standard errors of transformed data. nificantly higher in herbicide plots than in the nonherbicide plots in 1999 , but by 2000 there were no differences among treatments (Fig. 3c). Seedling counts in imazapic98 plots continued to decline in 2001, but other treatments did not differ. There was a significant treatment by year interaction $(F=10.88 ; \mathrm{df}=6,222 ; P<0.0001)$.

\subsection{Flea beetle relative abundance}

Both species of flea beetles varied in relative abundance between herbicide history and among years, but there was no significant interaction between the two variables. (A. lacertosa: $F=10.71, \quad \mathrm{df}=1, \quad 199, \quad P=0.0012$; $F=46.56, \mathrm{df}=2,313, P<0.0001$ and $F=0.69, \mathrm{df}=2$, $313, P=0.50$ for herbicide history, year and the interaction, respectively. A. nigriscutis: $F=16.27, \mathrm{df}=1,199$, $P<0.0001 ; \quad F=3.17, \quad \mathrm{df}=2, \quad 313, \quad P=0.043 \quad$ and $F=1.81, \mathrm{df}=2,313 P=0.17$ for herbicide history, year and the interaction, respectively.) Plots with a history of herbicide application had fewer flea beetles of each species than did those that had not been sprayed (Table 1). Both species of flea beetle had higher relative abundances in 2000 and 2001 than in 1999 (Table 1).

\subsection{Flea beetle-herbicide interaction}

\subsection{1. $1999-2000$}

We found significant differences $(P<0.05)$ in variance, path coefficients, and means between the herbicide and nonherbicide models for the first time step, 1999-2000. Variance in change in mature stems was much greater in herbicide than nonherbicide plots, while variance in $\log A$. lacertosa in 1999 was greater in untreated plots (Table 2). Five of the nine path coefficients varied significantly between herbicide and nonherbicide models (Fig. 4). Flea beetles did not significantly influence change in stems in either herbicide or nonherbicide plots. The negative effect

Table 1

Relative abundance of Aphthona lacertosa and A. nigriscutis on plots as distinguished by herbicide history and year ${ }^{\mathrm{A}}$

\begin{tabular}{llllll}
\hline Species & Herbicide history & Year & Estimate & SE & DF \\
\hline A. lacertosa & Not sprayed & & $2.80^{\mathrm{a}}$ & 0.21 & 199 \\
& Sprayed & & $1.95^{\mathrm{b}}$ & 0.15 & 199 \\
& & 1999 & $1.65^{\mathrm{a}}$ & 0.14 & 313 \\
& & 2000 & $2.67^{\mathrm{b}}$ & 0.14 & 313 \\
\multirow{4}{*}{. nigriscutis } & 2001 & $2.81^{\mathrm{b}}$ & 0.19 & 313 \\
& Not sprayed & & $3.15^{\mathrm{a}}$ & 0.17 & 199 \\
& Sprayed & & $2.28^{\mathrm{b}}$ & 0.12 & 199 \\
& & 1999 & $2.52^{\mathrm{a}}$ & 0.12 & 313 \\
& & 2000 & $2.77^{\mathrm{b}}$ & 0.12 & 313 \\
& 2001 & $2.86^{\mathrm{b}}$ & 0.17 & 313 \\
\hline
\end{tabular}

${ }^{\text {A }}$ Shown are least square means of log-transformed data. Means with the same letter within a treatment category (either herbicide history or year) did not differ significantly $(P>0.05)$. 
Table 2

Mean and variance of variables used in the structural equation models ${ }^{\mathrm{a}}$

\begin{tabular}{|c|c|c|c|c|c|c|}
\hline \multirow[t]{2}{*}{ Variable } & \multicolumn{3}{|c|}{ Herbicide } & \multicolumn{3}{|c|}{ Non-herbicide } \\
\hline & Mean & $N$ & Variance & Mean & $N$ & Varian \\
\hline $\log$ A. lacertosa 99 & 1.48 & 93 & 2.45 & 1.74 & 164 & 3.56 \\
\hline $\log$ A. nigriscutis 99 & 1.71 & 93 & 2.50 & 2.28 & 164 & 3.74 \\
\hline $\log$ A. lacertosa 00 & 2.70 & 93 & 4.37 & 2.53 & 164 & 4.01 \\
\hline $\log A$. nigriscutis 00 & 2.08 & 93 & 2.90 & 2.72 & 164 & 2.96 \\
\hline Change in stems $99-00$ & 1.03 & 93 & 600.84 & -0.59 & 164 & 221.90 \\
\hline $\log$ stems 99 & 2.40 & 93 & 1.48 & 2.91 & 164 & 1.15 \\
\hline $\log$ A. lacertosa 01 & 2.50 & 93 & 2.90 & 2.51 & 163 & 3.51 \\
\hline $\log A$. nigriscutis 01 & 2.16 & 93 & 2.08 & 2.75 & 163 & 2.77 \\
\hline Change in stems $00-01$ & -9.16 & 93 & 316.35 & -14.20 & 163 & 342.02 \\
\hline $\log$ stems 00 & 2.45 & 93 & 1.59 & 2.82 & 163 & 1.37 \\
\hline
\end{tabular}

${ }^{\text {a }}$ Numbers in bold indicate significant differences between herbicide and non-herbicide treatments, as determined by single degree of freedom Chisquare tests $(P<0.05)$.

of A. lacertosa in 1999 on A. nigriscutis in 2000 was accentuated in the herbicide compared with the nonherbicide plots. Stem density in 1999 had a stronger influence on change in stems, but less influence on flea beetle numbers in 2000 , in herbicide plots than in nonherbicide plots. Numbers of A. lacertosa in 2000 were more strongly dependent on their numbers in 1999 in the herbicide than the nonherbicide model. A weak negative correlation was observed between the two flea beetle species in 2000, as well as a weak positive correlation between A. nigriscutis in 2000 and change in stems, in both models. Only mean A. nigriscutis numbers in 1999 showed significant differences between herbicide and nonherbicide plots; fewer A. nigriscutis were present in herbicide plots (Table 2).

\subsection{2. $2000-2001$}

We found no significant differences between herbicide and nonherbicide data based on model results for the 2000-2001 time step. Variances, means, and path coefficients were all equivalent across the two groups (Table 2 and Fig. 4).

\section{Discussion}

We found little evidence for long-term benefits of herbicide applications at our study areas in Theodore Roosevelt National Park. Effects of aerial applications of imazapic and picloram/2,4-D were transient, though they did result in reduced spurge stem density compared to biocontrol alone within the first 1-2 years after application. We found evidence, however, that these operational applications of herbicide had temporarily disrupted the established biocontrol program at the park. After $2-3$ years, plots treated with herbicide did not differ significantly in stem density from plots subjected to only biocontrol over the same time period.

\subsection{Comparison of effects of herbicide and biocontrol on leafy spurge stem counts}

We found no clear and consistent effects of operationally applied herbicide on mature leafy spurge stem counts. a

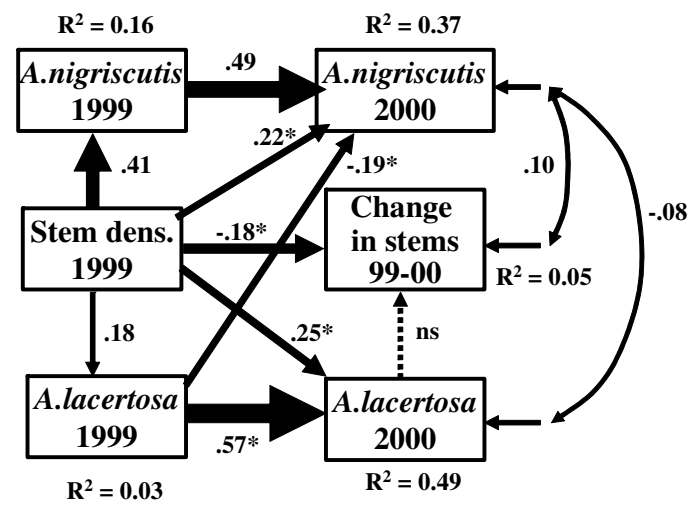

b
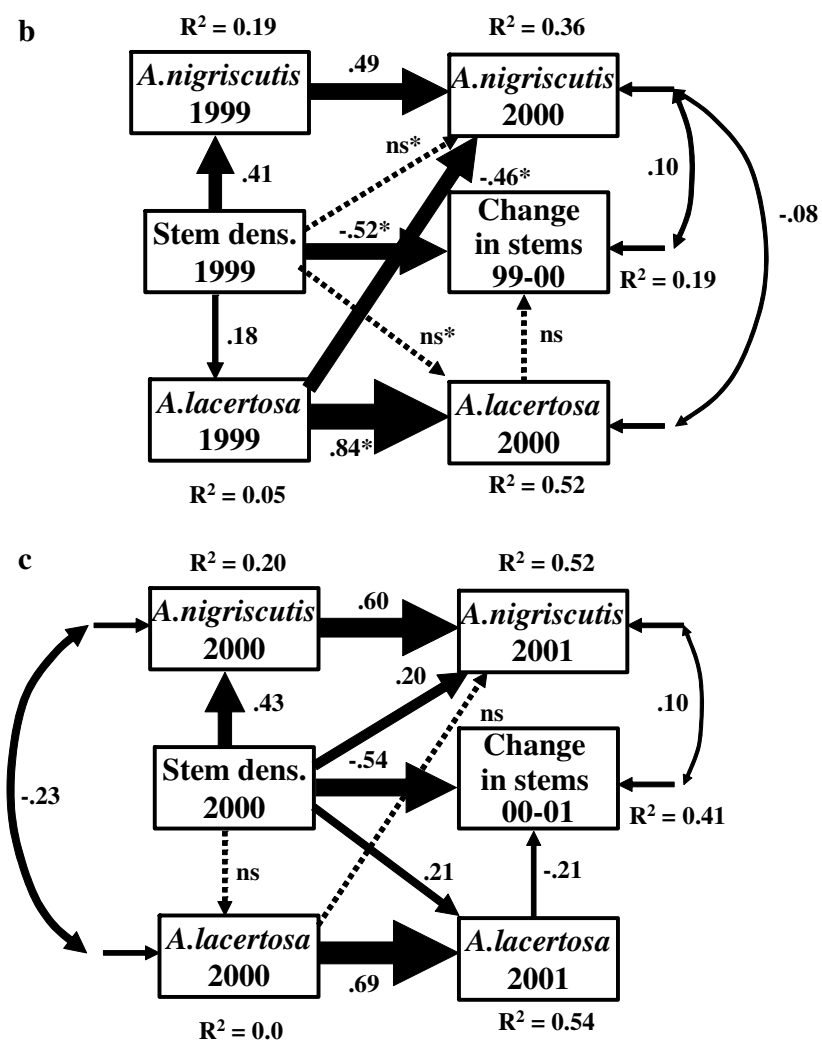

Fig. 4. Model results for (a) nonherbicide and (b) herbicide plots, 19992000 and (c) common results for herbicide and nonherbicide plots in 2000-2001. Uni-directional arrows indicate causal paths. Bi-directional arrows represent correlations, which were modeled by allowing for correlated error terms. Path coefficients are standardized and all solid arrows indicate significant paths $(P<0.05)$; size of the arrow reflects the magnitude of the path coefficient. The dashed arrow indicates a nonsignificant path that was considered biologically meaningful and so remains in the model. $R^{2}$ values are shown for dependent variables. Asterisks denote significant differences between herbicide and nonherbicide models in 1999-2000.

Although plots treated with herbicide had lower stem counts than biocontrol-only plots in some years, the effect was not consistent from year to year. The pattern of decline of mature stems in plots sprayed with picloram/2,4-D suggests a lag in effect, in that stem counts in 1999 were significantly lower than biocontrol-only plots for plots sprayed in 1997, but not 1998. By 2000, both picloram97 and 
picloram98 plots had significantly lower stem counts than biocontrol-only plots. In contrast, plots sprayed with imazapic in 1998 had significantly lower stem counts than biocontrol-only plots only in 1999. These results are similar to those found by Lym (2005) in an experiment designed to compare effects of imazapic with those of Aphthona in the sandier soils of southeastern North Dakota. Although he found a significantly greater decline in stems in the year following treatment on imazapic-treated plots, by the second year there were no significant differences among imazapic, imazapic + Aphthona, and Aphthona only plots, and this lack of difference continued into the third year posttreatment.

Whether sprayed in 1997 or 1998, all herbicide plots had significantly greater numbers of leafy spurge seedlings in 1999 than did the biocontrol-only plots. Survival of seedlings generally is low (Selleck et al., 1962), however, and this did not obviously translate directly into higher counts of mature stems on herbicide plots in 2000 . Nonetheless, if conditions are favorable, leafy spurge populations may plausibly be increased by such high seedling recruitment, even though this did not happen in our study. Although plots sprayed with imazapic in 1998 had significantly lower seedling counts in 2001, this difference is likely unrelated to the herbicide, since its half-life in soil is only 120 days.

\subsection{Interactions between herbicide and flea beetles}

Populations of both $A$. lacertosa and A. nigriscutis were lower in plots with a history of herbicide than in Aphthonaonly plots. In a study of factors influencing dispersal of $A$. lacertosa, Van Hezewijk and Bourchier (2005) found that the flea beetles showed preferences based on reproductive status of spurge ramets in one experiment, but showed a preference for ramet density in a second experiment; differences they suggested might relate to variation among spurge clones. Herbicide plots in our study tended to have a smaller percentage of flowering stems than did Aphthonaonly plots. In addition to reduced abundance of spurge in herbicide plots, plants that have survived herbicide application may provide fewer nutrients to herbivores than plants that have not experienced such a stress (Messersmith and Adkins, 1995). If $A$. nigriscutis is more mobile than A. lacertosa in this study area, as Jonsen et al. (2001) found in similar habitat, A. nigriscutis may be more likely to abandon herbicide-controlled patches for greater resource availability elsewhere. Results of the structural equation models indicated that the relationship between previous year's spurge density and current year's relative abundance of A. lacertosa and A. nigriscutis was abolished by herbicide application that had occurred 1-2 years prior, but that the relationship was reestablished 2-3 years post-herbicide. Nelson and Lym (2003) found no direct negative effects of picloram/2,4-D on A. nigriscutis, although Lym and Nelson (2002) consistently found higher numbers of flea beetles of both species in their nonherbicide plots compared to those sprayed with various herbicides. Thus, it seems most likely that effects on Aphthona density are mediated through resource availability rather than direct effects of the herbicide.

The differences in the herbicide and nonherbicide structural equation models for 1999-2000 suggest that herbicide resulted in an increase, compared to nonherbicide plots, in a negative interaction between $A$. nigriscutis and A. lacerto$s a$. Because leafy spurge stem counts were lower in herbicide than in Aphthona-only plots in 1999-2000, our results are consistent with the notion that the two species may compete for leafy spurge (or interfere with each other in some other way), although our retrospective study cannot demonstrate that resources were limiting. Competition is not uncommon among weed biological control insects when more than one species is released (Denno et al., 1995).

Higher variance in change in mature stem counts between 1999 and 2000 in herbicide than in nonherbicide plots suggests more variability in the herbicide-treated area. This may reflect patchiness in application achieved by aerial spraying, or may be a result of combining the three different applications into a more general "herbicide" treatment. Nonetheless, the lack of significant differences between any aspect of the herbicide and nonherbicide models in 2000-2001 suggests that the effect of the herbicide was not long-term.

We emphasize that this study evaluated an operational IPM program. Treatments were applied to address management concerns, not to facilitate research via an a priori experimental design. Nonetheless, results are consistent with rigorously designed experimental studies (e.g., Lym, 2005; Nelson and Lym, 2003). Interestingly, Lym (2005) concluded that the use of the herbicide was warranted at his study site, while we would suggest that, at TRNP, reliance on the flea beetles alone would have been more advantageous. This contrast emphasizes the key role of management goals. In Lym's (2005) study, the goal was to protect habitat of an endangered orchid and the quicker response by leafy spurge after herbicide application was more desirable than the slower decline attributed to flea beetles alone, despite the added expense of herbicides. At TRNP, the goal was a more general desire to curtail the spread of leafy spurge along these drainages; given that both herbicide and biocontrol achieved the same results, albeit over a somewhat different time period, the additional cost of herbicide may be harder to justify. Funds spent on unnecessary control actions necessarily detract from funds available for other control activities. It is also important to recognize that, in 1997, it was unclear that leafy spurge biocontrol would be as successful at TRNP as it has been. Ainsworth (2003) made the point that it is often some time before efficacy of biocontrol is accepted, and in the meantime, herbicide application continues regardless of biocontrol status.

Biocontrol with flea beetles is not always effective in reducing the abundance of leafy spurge in the northern Great Plains (Kirby et al., 2000), with control reportedly varying between $0 \%$ and $95 \%$ (Nelson and Lym, 2003). The need 
for careful post-treatment monitoring is therefore clear. However, once a biocontrol effort has been found to be successful, there would seem to be little advantage gained from the extra expense and effort of herbicide application.

\section{Acknowledgments}

We appreciate the help of a small army of field assistants without whom this study would not have been possible. The manuscript has been improved by comments from Q. Guo, K. Kraft, D. Ragsdale, and T. Shaffer. Support was provided by USGS Natural Resources Preservation Program and Northern Prairie Wildlife Research Center, and by Theodore Roosevelt National Park. We are grateful to Raghavan Charudattan and two anonymous reviewers for advice on ways of improving the manuscript.

\section{References}

Ainsworth, N., 2003. Integration of herbicides with arthropod biocontrol agents for weed control. Biocontrol Sci. Technol. 13, 547-570.

Anderson, G.L., Everitt, J.H., Escobar, D.E., Spencer, N.R., Andrascik, R.J., 1996. Mapping leafy spurge (Euphorbia esula) infestations using aerial photography and geographic information systems. Geocarto Int. $11,81-89$.

Belcher, J.W., Wilson, S.D., 1989. Leafy spurge and the species composition of a mixed-grass prairie. J. Range Manage. 42, 172-175.

Butler, J.L., Cogan, D.R., 2004. Leafy spurge effects on patterns of plant species richness. J. Range Manage. 57, 305-311.

Butler, J.L., Trammell, M.A., 1995. Final Report: Exotic plants of Theodore Roosevelt National Park: extent, distribution and ecological impact. University of South Dakota, Vermillion, SD.

Caesar, A.J., 2003. Synergistic interaction of soilborne plant pathogens and root-attacking insects in classical biological control of an exotic rangeland weed. Biol. Control. 28, 144-153.

Denno, R.F., McClure, M.S., Ott, J.R., 1995. Interspecific interactions in phytophagous insects - competition reexamined and resurrected. Annu. Rev. Entomol. 40, 297-331.

Gassmann, A., Schroeder, D., Maw, E., Sommer, G., 1996. Biology, ecology, and host specificity of European Aphthona spp. (Coleoptera, Chrysomelidae) used as biocontrol agents for leafy spurge, Euphorbia esula (Euphorbiaceae), in North America. Biol. Control 6, 105-113.

Grace, J.B., 2003. Comparing groups using structural equations. In: Pugesek, B., Tomer, A., Von Eye, A. (Eds.), Structural Equation Modeling: Applications in Ecological and Evolutionary Biology Research. Cambridge University Press, New York, pp. 281-296.

Grace, J.B., 2006. Structural Equation Modeling and Natural Systems. Cambridge University Press, Cambridge, UK.

Hansen, R.W., Richard, R.D., Parker, P.E., Wendel, L.E., 1997. Distribution of biological control agents of leafy spurge (Euphorbia esula L.) in the United States: 1988-1996. Biol. Control. 10, 129-142.

Hollingsworth, C.S., Coli, W.M., 2001. IPM adoption in Northeastern US: An examination of the IPM continuum. Am. J. Altern. Agr. 16, 177-183.

Holtzer, T.O., Anderson, R.L., McMullen, M.P., Peairs, F.B., 1996. Integrated pest management of insects, plant pathogens, and weeds in dryland cropping systems of the Great Plains. J. Prod. Agr. 9, 200-208.
Jonsen, I.D., Bourchier, R.S., Roland, J., 2001. The influence of matrix habitat on Aphthona flea beetle immigration to leafy spurge patches. Oecologia 127, 287-294.

Jöreskog, K.G., Sörbom, D., 1996. LISREL 8: User's Reference Guide. Scientific Software International, Chicago, IL.

Kirby, D.R., Carlson, R.B., Krabbenhoft, K.D., Mundal, D., Kirby, M.M., 2000. Biological control of leafy spurge with introduced flea beetles (Aphthona spp.). J. Range Manage 53, 305-308.

Larson, D.L., Grace, J.B., 2004. Temporal dynamics of leafy spurge (Euphorbia esula) and two species of flea beetles (Aphthona spp.) used as biological control agents. Biol. Control 29, 207-214.

Larson, D.L., Anderson, P.J., Newton, W., 2001. Alien plant invasion in mixed-grass prairie: effects of vegetation type and anthropogenic disturbance. Ecol. Appl. 11, 128-141.

Lym, R.G., 1998. The biology and integrated management of leafy spurge (Euphorbia esula) on North Dakota rangeland. Weed Technol. 12, $367-373$.

Lym, R.G., 2005. Integration of biological control agents with other weed management technologies: Successes from the leafy spurge (Euphorbia esula) IPM program. Biol. Control 35, 366-375.

Lym, R.G., Nelson, J.A., 2000. Biological control of leafy spurge (Euphorbia esula) with Aphthona spp. along railroad right-of-ways. Weed Technol. 14, 642-646.

Lym, R.G., Nelson, J.A., 2002. Integration of Aphthona spp. flea beetles and herbicides for leafy spurge (Euphorbia esula) control. Weed Sci. 50, 812-819.

McCune, B., Grace, J.B., 2002. Analysis of Ecological Communities. MjM Software Design, Gleneden Beach, OR.

McCune, B., Mefford, M.J., 1997. PC-ORD. Multivariate Analysis of Ecological Data, Version 3.0. MjM Software Design, Gleneden Beach, OR

Messersmith, C.G., Adkins, S.W., 1995. Integrating weed-feeding insects and herbicides for weed control. Weed Technol. 9, 199-208.

Milliken, G.A., Johnson, D.E., 1984. Analysis of Messy Data: Designed Experiments. Van Nostrand Reinhold, New York, New York.

Mortensen, D.A., Bastiaans, L., Sattin, M., 2000. The role of ecology in the development of weed management systems: an outlook. Weed Res. 40, 49-62.

Nelson, J.A., Lym, R.G., 2003. Interactive effects of Aphthona nigriscutis and picloram plus 2,4-D in leafy spurge (Euphorbia esula). Weed Sci. $51,118-124$.

Pugesek, B., Tomer, A., Von Eye, A. (Eds.), 2003. Structural Equation Modeling: Applications in Ecological and Evolutionary Biology Research. Cambridge University Press, Cambridge, UK.

SAS Institute, Inc. 1999, SAS OnlineDoc ${ }^{\circledR}$, Version 8. SAS Institute Inc., Cary, NC

Selleck, G.W., Coupland, R.T., Frankton, C., 1962. Leafy spurge in Saskatchewan. Ecol. Monogr. 32, 1-29.

Shipley, B., 2000. Correlation and Causation in Biology. Cambridge University Press, Cambridge, UK.

USDA, NRCS, 2006. In: Skinner, M.W.(Ed.), The PLANTS Database, Version 3.5, vol. 2006, Baton Rouge, LA. Available from: <http:// plants.usda.gov>.

Van Hezewijk, B.H., Bourchier, R.S., 2005. Is two company or a crowd: how does conspecific density affect the small-scale dispersal of a weed biocontrol agent? Biocontrol Sci. Technol. 15, 191-205.

van Wilgen, B.W., Willems, T., Van der Heyden, F., Zimmermann, H.G., Magadlela, D., 2000. Big returns from small organisms: developing a strategy for the biological control of invasive alien plants in South Africa. S. Afr. J. Sci. 96, 148-152. 